UDC 621.311 .16 .012 .8

$518.6: 512.83$

\title{
電力潮流問題におけるくり返し計算法の 収束と誤差修正
}

\author{
東京工業大学 渡辺成良 \\ 東京工業大学 深 尾毅
}

\section{1.はじめに}

電力潮流計算へ線琲解法に用いるくり返し計算法を 適用した解析法は，従来加広く取り上げられている。 て礼は電力潡流計算が非線形解析であるにもかかわら ず，簡単に線形近似の問題八变換できるととと，くり 返し計算法ぶ単純でしかも簡便なためである。

電力潮流訫算の手法として節点アドミッタンス行列 を用いたくり返し計算法は，計算が単純で回路網变更 に対する適応性が高く計算機内での記憶容量がほぼ最 小ですみ，しかも反復計算の各ステップで必要な計算 量は最小でよいなどの利点を有しており，正しい解へ の収束が罣いという欠点も本文で述べる捠差修正法を 满用するこよにより改善できる。

誤差修正法は，絶対値最大の固有値を求的る乘べき 法（入力条件が異なるだけでくり返し計算法之同一の 計算式を用いる）の収束の過程加ら節点電圧の収束の 過程を推測し，真值との誤差を評洒してすみやかに正 しい解に近つけようとする外之う法である。

線形回路䋧の問题に対する俱差修正法はすでに述へ たが, (1) 本文はこれを应張し，電力潮流計算において くり返し計算法が真值へ収束するために必要な条件と その収束の判定法を明白にし，乗べき法の収束之節点 電王の收束之の関保および啡差修正法の適用アルゴリ スムを述べるまた AEP 模擬 30 節点回路へ適用し た結果を示亦。

おお本文では既知の線路つドミッタンスと節点へ注 入される有効执上び無効電力を用い，末知の節点電王 を算出する。（基準節点在除いて $P-Q$ 指定）この節

Convergence and Error Correction of Iterative Methods for Power Flow Problem. By S. WATANABE, Associate, \& T. FUKAO, Member (Tokyo Institute of Technology)

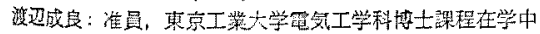

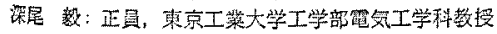

点電圧の計算にくり返し計算法が適用される。

\section{2. くり返し計算法による節点電圧の計算}

n一節点からなる回路の節点方程式は，

$$
\boldsymbol{Y} E=F[E]
$$

により示される。 $F(E)$ は $n$ 次元の関数べクトルで， この $p$ 番目の要素は

$$
F_{p}[E]=\left(P_{p}-j Q_{p}\right) / \bar{E}_{p} \quad p=1,2, \cdots, n
$$

である。( $\vec{E}_{p} は \dot{E}_{p}$ の共役複素数) ここで節点電压, 節点アドミッタンス行列, 注入有效および無効電力を

$$
\begin{aligned}
& E=\left[\begin{array}{c}
E_{1} \\
\vdots \\
E_{n}
\end{array}\right], \quad \boldsymbol{Y}=\left[\begin{array}{ccc}
\dot{y}_{11} \cdots \dot{y}_{1 n} \\
\vdots & \ddots & \vdots \\
\dot{y}_{n 1} & \cdots & \dot{y}_{n n}
\end{array}\right], \quad P=\left[\begin{array}{c}
P_{1} \\
\vdots \\
\dot{P}_{n}
\end{array}\right], \\
& Q=\left[\begin{array}{c}
Q_{1} \\
\vdots \\
Q_{n}
\end{array}\right]
\end{aligned}
$$

と寸る。以下において電圧が指定された基準節点を $n$ 番目とする。

（1）式の解は反復計算に上り求めら机，解法上して

(i) ニュートンーラフソン法

(ii) 線形近似解法

(iii) 非線形計画法

などがあげられる。（ii)の反復計算は $m$-ステップで

$$
\boldsymbol{Y} E(m+1)=F[E(m)]
$$

〔 $E(m)$ は既知〕なる線形方程式を解き， $E(m+1)$ が収束するまで反復される。線形解法上してガウス消 去法，線形くり返し計算法などが若えられる。

本諭文では（ii）に拉いて線形くり返し計算法老应 張したくり返し計䍌法が用いられる。(文献（2）在参 照) 線形くり返し計算法は，(2)式に和いて左刃 $E(m$ +1)を末知とし右边を既知とした線班方程式をヤコビ 法，ガウスーザイデル法または加速計箩法により反復 計算す机ばあるl回の反復で収束し， $E(m+1)$ が得 ら机たことになるが（したがってl回の反得計算中で 
右辺の $F[E(m)]$ は変更されない)，本文のくり返し 計算法は，各反復計算（線形力程式をくり返し計算法 で解いているときの反復計算)で得られた新しい解を 用いて（2）式の右刃を置き加えることになる。すな わち線形くり返し計算法において $l=1$ で打ち切った 結果を新しい解 $E(m+1)$ としたことになる。

したがって，ヤコビ法またはガウスーザイデル法は

$$
\begin{aligned}
& \dot{E}_{p}(m+1)=\frac{1}{\dot{y}_{p p}}\left\{-\sum_{\substack{q=1 \\
q \neq p}}^{n-1} \dot{y}_{p q} \dot{E}_{q}(m)+\frac{P_{p}-j Q_{p}}{E_{p}(m)}\right. \\
& \left.\quad-\dot{y}_{p n} \dot{E}_{n}\right\}
\end{aligned}
$$

または

$$
\begin{array}{r}
\dot{E}_{p}(m+1)=\frac{1}{\dot{y}_{p p}}\left\{-\sum_{q=1}^{p-1} \dot{y}_{p q} \dot{E}_{q}(m+1)\right. \\
-\sum_{q=p+1}^{n-1} \dot{y}_{p q} E_{q}(m)+\frac{P_{p}-i Q_{p}}{\dot{E}_{p}(m)} \\
\left.-\dot{y}_{p n} \dot{E}_{n}\right\} \quad p=1,2, \cdots, n-1
\end{array}
$$

となり，加速定数を $\omega$ とすれば加速計算法は

$$
\begin{array}{r}
\dot{E}_{p}(m+1)=\dot{E}_{p}(m)+\omega\{((3) \text { 式の右辺 }] \\
\left.-\dot{E}_{p}(m)\right\} \quad \ldots \ldots \ldots \ldots \ldots \ldots \ldots \ldots \ldots \ldots \ldots \ldots
\end{array}
$$

ただし $m$ ：反復回数， $E(0)$ : 初期想定電压

である。これらのくり返し計算法は，いずれも行列表 示によって

$$
E(m+1)=\boldsymbol{M} E(m)+\boldsymbol{N}^{-1} I(m)
$$

上毒ける。ここでベクトル $I(m)$ の要素は

$$
\begin{aligned}
& \dot{I}_{p}(m)=\left(P_{p}-j Q_{p}\right) / \bar{E}_{p}(m)-\dot{y}_{p n} \dot{E}_{n} \\
& p=1,2, \cdots, n-1
\end{aligned}
$$

であり，行列 $D, L ， U$ 在をれでれ基準節点の行上 列を除いた $\boldsymbol{Y}$ の対角，下三角，上三角要素加なる 6の上寸れば（4) 式の行列 $\boldsymbol{M}$ 上 $N$ は各くり返し 計算法に対して第 1 表のように示される。

あし，注入電流が指定されれば，(4)式は線玩くり 返し計算式となり，真值 $E$ 人の収束条件は行列 $\boldsymbol{M}$ のスペクトル半径 $\rho(\boldsymbol{M})$ が1以下である。とこるが $I(m)$ は反復回数 $m$ により変動するから，一般に(4) 式の収束条件は $\rho(\boldsymbol{M})$ で議論できない。ここで各節点 電圧の大きさがすべ 1.0 付近の值であること（以下 こ机を $E$ の望ましい解と呼ふ）加普通であることか

\begin{tabular}{|c|c|c|}
\hline 乾算法行 列 & $M$ & $\boldsymbol{N}$ \\
\hline $\begin{array}{l}\text { ヤコビ法 } \\
\text { ガウスーザイデル法 }\end{array}$ & $\begin{array}{l}-D^{-1}(L+U) \\
-(D+L)^{-1} U\end{array}$ & $\begin{array}{l}D \\
D+L\end{array}$ \\
\hline $\begin{array}{l}\text { ガウスーザイデル加速部算法 } \\
(1 \leq \omega<2)\end{array}$ & $\begin{array}{l}-(D+\omega L)^{-1} \\
\times\{\omega U+(\omega-1) D\}\end{array}$ & $\frac{1}{\omega}(\boldsymbol{D}+\omega \boldsymbol{L})$ \\
\hline
\end{tabular}
ら，乙の望ましい解への取束条件 (十分条件) 在求め てみる。

\section{3. くり返し計算法の収束条件}

(4) 式で示ざれた準線形力程式におけるくり返し計 算法の取束条件を調べてるる。反復計算の $m$ 回日に
第 1 表 節点アドミッタンス行列とくり返 し行列と口関係

Table 1. Relation between admittance matrix and iterative matrix $(\boldsymbol{Y}=\boldsymbol{D}+\boldsymbol{L}+\boldsymbol{U})$.

おける真值との誤差を，

$$
\Delta(m) \triangleq E-E(m)
$$

とすれば，(4)式から

$$
\Delta(m)=G_{m-1}[\Delta(m-1)]
$$

と示せる。ただし作用素 $G_{k}$ はぶクトル $V$ に対して

$$
G_{k}[V]=\boldsymbol{M} V-\boldsymbol{N}^{-1} \boldsymbol{R}(k) \bar{V}
$$

であり $(\bar{V}$ は $V$ 複素共役ベクトル $)$

$$
\boldsymbol{R}(k)=\left(\begin{array}{cc}
\frac{P_{1}-j Q_{1}}{\bar{E}_{1} \tilde{E}_{1}(k)} & 0 \\
0 & \ddots \\
\frac{P_{n-1}-j Q_{n-1}}{\tilde{E}_{n-1} \bar{E}_{n-1}(k)}
\end{array}\right)
$$

とする。(5)式加ら

$$
\Delta(m)=G_{m-1}\left[G_{m-2}\left[\cdots\left[G_{0}[\Delta(0)]\right] \cdots\right]\right](7)
$$

したがって，有限の要菜からなる $\Delta(k)$ に対して

$$
\left\|G_{k}[\Delta(k)]\right\|<\infty, \quad k=0,1,2, \cdots
$$

および，あるp 以上の $k$ に詨して

$$
\left\|G_{k}[\Delta(k)]\right\|<\|\Delta(k)\|
$$

であ机ば

$$
\lim _{m \rightarrow \infty}\|\Delta(m)\|=0
$$

となる。この収束条件は一般に複雑であるから，次の ような解析を行なう。すなわち，ベクトルV $V$ を実部 と虚部に分解して（6）式を書き加觉

$$
\left.\begin{array}{rl}
V=V_{\text {real }} & +j V_{\text {img }} \\
G_{k}(V)= & \left\{\boldsymbol{M}-\boldsymbol{N}^{-1} \boldsymbol{R}(k)\right\} V_{\text {real }} \\
& +j\left\{\boldsymbol{M}+\boldsymbol{N}^{-1} \boldsymbol{R}(k)\right\} V_{\text {img }}
\end{array}\right\}
$$

とおく。ここで枝のインピーダンスにおける抵抗分を $R$ ，リアクタンス分を $X$ としたよき，す心゙ての枝で $R$ ŁXの比等しけれげ，第 1 表より加速なしのく り返し行列 $\boldsymbol{M}$ は非負行列（要素が正または零）とな ることが示される。(1)一般に次の性質が導加れる。 性質 1 回路を構成する枝のほとんじにおいて， $0 \leq R / X \ll 1$ 逆に $R / X \gg 1$ の場合, あるいは $R / X$

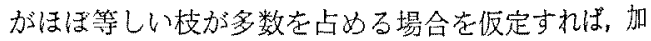
速なしのくり返し行列 $\boldsymbol{M}$ の要荸はこの条件を満たす 
第 2 表 $R / X$ が同一の範囲にある枝が全体の枝に占める割合い

Table 2. Percentage of branches whose $R / X$ exists in some segment.

\begin{tabular}{r|r|r|r|r|r|r|r|r|r|r}
\hline 筇点数 & $0.0 \sim 0.1$ & $0.1 \sim 0.2$ & $0.2 \sim 0.3$ & $0.3 \sim 0.4$ & $0.4 \sim 0.5$ & $0.5 \sim 0.6$ & $0.6 \sim 0.7$ & $0.7 \sim 0.8$ & $0.8 \sim 0.9$ & $0.9 \sim$ \\
\hline 6 & 28.6 & 0.0 & 42.8 & 0.0 & 14.3 & 0.0 & 14.3 & 0.0 & 0.0 & 0.0 \\
18 & 0.0 & 26.1 & 17.4 & 39.1 & 4.4 & 13.0 & 0.0 & 0.0 & 0.0 & 0.0 \\
30 & 17.1 & 2.4 & 12.2 & 19.5 & 24.4 & 17.1 & 4.9 & 0.0 & 0.0 & 2.4 \\
57 & 22.5 & 6.3 & 11.2 & 13.8 & 3.7 & 2.5 & 27.5 & 7.5 & 2.5 & 2.5 \\
118 & 10.6 & 6.7 & 43.0 & 38.0 & 1.1 & 0.0 & 0.0 & 0.0 & 0.0 & 0.6 \\
\hline
\end{tabular}

枝に対応する要素と対角要素において，虚部の大きさ は実部（すべて非負）に此べ小さくなる。特に $R / X$ がすべて等しい枝からなる回路では $\boldsymbol{M}$ は非負行列。

性質 2 性犋 1 の仮定老満犬卞回路で加速なしの くり返し行列 $\boldsymbol{M}$ は実部が正で，虚部の大きさは军部 に比へ小さい上うな絶対值最大の固有值をもつ。特に $R / X$ がすべて等しい枝からなる回路では，虚部は存 在しない。

この議諭は $\boldsymbol{M}$ の要素の虚部が実部に比べて小さい という性質を用い，実数（非負）行列に虚部の摄動項 加加わったもの上考元て。行列 $\boldsymbol{M}$ を $\boldsymbol{M} \equiv \boldsymbol{M}_{1}+j \in \boldsymbol{M}_{2}$ 之おいたとき $(\epsilon \ll 1) ， \boldsymbol{M}$ の固有值 $\lambda$ は $\boldsymbol{M}_{1}$ の固有 值 $\lambda_{1}$ と

$$
\lambda=\lambda_{1}+j \in K_{1}-\epsilon^{2} K_{2}+\cdots \cdots
$$

の関係で就き換えられることを用いている。ここで， $K_{1}, K_{2}, \cdots \cdots$ は $\boldsymbol{M}_{1}$ および $\boldsymbol{M}_{2}$ 加ら定まる。(文献 (3) 参照)

さて（8) 式で，行列を置き換えて

$$
\boldsymbol{S}_{k}^{-} \equiv \boldsymbol{M}-\boldsymbol{N}^{-1} \boldsymbol{R}(k), \quad \boldsymbol{S}_{k}^{+} \equiv \boldsymbol{M}+\boldsymbol{N}^{-1} \boldsymbol{R}(k)
$$

とし，行列 $\boldsymbol{S}_{k}^{-}$之 $\boldsymbol{S}_{k}{ }^{+}$の性質を調へる。

性質3 $\boldsymbol{S}_{k}^{-} ， \boldsymbol{S}_{k}{ }^{+}$は，実係数行列に打ずかな虚 数成分加らなる行列力加扐った複素係数行列上仮定す る。このときある $p$ 以上の全てのkについて

$$
\rho\left(\boldsymbol{S}_{k}^{-}\right)<1 \text { および } \rho\left(\boldsymbol{S}_{k}^{+}\right)<1
$$

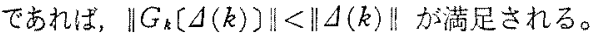

いま，回路網が性質 1 の仮定を満たし，ガウスーザ イデル法で計算を行なうとすれば(ヤコビ法も同様)， 行列 $\boldsymbol{S}_{k}^{-}, \boldsymbol{S}_{k}{ }^{+}$は第 1 表加ら

$$
\left.\begin{array}{l}
\boldsymbol{S}_{k}^{-}=-\boldsymbol{N}^{-1}\{\boldsymbol{U}+\boldsymbol{R}(k)\} \\
\boldsymbol{S}_{k}{ }^{+}=-\boldsymbol{N}^{-1}\{\boldsymbol{U}-\boldsymbol{R}(k)\}
\end{array}\right\}
$$

と書訬る。ことで行列 $\boldsymbol{R}(k)$ は $r_{i}(k) \equiv\left(P_{i}-j Q_{i}\right) / \bar{E}_{i} \bar{E}_{i}(k)$ を詨角要素酒つ（注 入電力がない節点 $i$ は雾，虚部はには無効電力に等し (）対角行列であるから， $\boldsymbol{S}_{k}^{-}, \boldsymbol{S}_{k}{ }^{+}$の要素は $\boldsymbol{M}$ の 要素の中で，対角を含む下三角部分（ヤコビ法では対
角部分だけ)が注入笔力によって変化したもの上なる。 （上三角部分は $\boldsymbol{M}$ 之同一）

したがって，性質 1 を満たすならば， $\boldsymbol{S}_{k}^{-}$と $\boldsymbol{S}_{k}{ }^{+}$ は性質 3 の仮定を満足することになり，収束の判定は 次の上うになる。すなわち

性翼 4 電力潮流計算をくり返し計算法で解く場 合に，与えられた回路網が性質 1 を満足したとき，あ る $p$ 以上の全ての $k$ について

$$
\rho\left(\boldsymbol{S}_{k}^{-}\right)<1 \text { および } \rho\left(\boldsymbol{S}_{k}^{+}\right)<1
$$

であれば，反復計算は真值八収束する。

典型的な模擬回路 6，18，30，56，118 節点につい て性質 1 沾よ゙ 2 を調べてみる。第 2 表はたとえば， $R / X$ が 0.0 0.1 の間仙ある枝が全体の枝に占的る 割合 (百分率)を示したもので，0.1問隔にまとめて 表わした。118 節点では $R / X$ が $0.26 \sim 0.36$ の間に ある枝が $70 \%$ 近くを占めている。これらの回路につ いてガウスーザイデル法 $(\omega=1.0)$ によるくり返し行 列の絶対值最大の固有值を第 3 表に示した。6 節点回 路を除いて虚部は実部に比べ $1 \%$ 以下となっている。

絶対值最大の固有值 $\lambda_{1}$ および $\rho\left(\boldsymbol{S}_{k}{ }^{+}\right)$上 $\rho\left(\boldsymbol{S}_{k}^{-}\right)$ は，付録Iおよび II が示すように同一のくり返し計 算法加ら得られる。

第1图の6 節点回路（第 2 表で用いた 6 節点回路の $R / X$ を $1 / 3$ とし対地容量はない）について，ガウス ーザイデル法 $(\omega=1.0)$ の $\rho(\boldsymbol{M})$ ，および真值 $E$ を 用いないで近似的に

$$
r_{i}(k)=\left(P_{i}-j Q_{i}\right) /\{\bar{E}(k)\}^{2}
$$

\begin{tabular}{|c|c|c|c|}
\hline 笁点数 & 絶対伵最大固有值 & 的点数 & 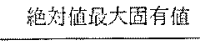 \\
\hline 6 & $0.783063-j 0.014741$ & 57 & $0.982868+j 0.003808$ \\
\hline 18 & $0.977349+j 0.004999$ & 118 & $0.997403-j 0.000706$ \\
\hline 30 & $0.974201+j 0.00441 .3$ & & \\
\hline
\end{tabular}

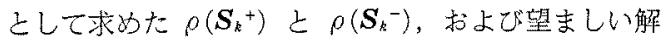
が実部は 1.0 付近で虚部は小なることから

第 3 表 模擬回路に招けるガウスーザイデル法 のくり返し行列の絶刘值最大固有值 $(\omega=1)$

Table 3. Maximal eigenvalue of Gauss-Seidel iterative matrix for test systems. $(\omega=1.0)$ 


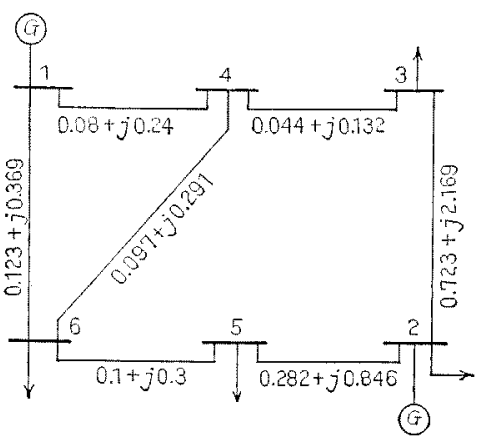

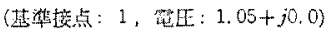

第 1 因 6 節点回路

Fig. 1. A sample network with 6 busses.

$$
r_{i}{ }^{0}=P_{i}-j Q_{i}
$$

し近仪して $\rho\left(\boldsymbol{S}_{0}^{+}\right)$と $\rho\left(\boldsymbol{S}_{0}{ }^{-}\right)$在計算した結果を第 4 表に示す。反復計算は 15 回行なわ机た。注入電力は 第 5 表にある。これによれば $\rho\left(\boldsymbol{S}_{k}{ }^{-}\right)>\rho(\boldsymbol{M})$ であり， 線形問題における収束の速さに比へて，潮流計算法で は取束加選くなることがわかる。

\section{4. 誤差の評価と誤差修正法}

与えられた回路の条件がくり返し計算法の収束条件 它満足していれだ，加速法を含めた反復計算が実行で きる。このよき（4）式変形するために，p番目の 要素力

$$
\begin{aligned}
\dot{I}_{p}=\left(P_{p}-j Q_{p}\right) / \bar{E}_{p}-\dot{y}_{p n} \dot{E}_{n} & \\
& p=1,2, \cdots, n-1
\end{aligned}
$$

であるべタトルIを用い

$$
\varepsilon(m)=N^{-1}\{I-I(m)\}
$$

と打けけ（4) 式は

$$
\begin{aligned}
E(m)= & \boldsymbol{M} E(m-1)+\boldsymbol{N}^{-1} I-\varepsilon(m-1) \\
= & \boldsymbol{M}^{m} E(0)+\left(\boldsymbol{I}+\boldsymbol{M}+\cdots+\boldsymbol{M}^{m-1}\right) \boldsymbol{N}^{-1} I \\
& -\left(\boldsymbol{M}^{m-1} \varepsilon(0)+\cdots+\boldsymbol{M} \varepsilon(m-2)\right. \\
& +\varepsilon(m-1)] \ldots \ldots \ldots \ldots \ldots \ldots \ldots \ldots(11)
\end{aligned}
$$

ここで $I$ : 站位行列

$$
\text { 亡なる。 }
$$

反復部算を実行すれば (11) 式の右䜣第二愐が真随 の霆圧八，他の項はすべてある愦差簿国に収束する。 また反復計算の $m$ 回目に㧍ける真值上の䛊差は，

(11)式を朋いて

\begin{tabular}{|c|c|c|c|}
\hline $\begin{array}{c}\text { 和速定数 } \\
\omega \\
\end{array}$ & 1.0 & $\begin{array}{c}\text { 伍速定数 } \\
\omega\end{array}$ & 1.0 \\
\hline$\rho(M)$ & $10.7118-j 0.01$ & $\rho\left(S_{0}^{+}\right)$ & $|0.66916+j 0.00807|$ \\
\hline$\rho\left(S_{k^{+}}\right)$ & $10.61921-j 0.007051$ & $\rho\left(S_{0}^{-}\right)$ & $|0.72523+j 0.04572|$ \\
\hline$\rho\left(S_{k^{-}}\right)$ & $|0.76504+j 0.03314|$ & & \\
\hline
\end{tabular}

$$
\begin{aligned}
\Delta(m)= & \sum_{i=m}^{\infty} \boldsymbol{M}^{i} \boldsymbol{N}^{-1} I+\sum_{i=0}^{m-1} \boldsymbol{M}^{m-1-i} \varepsilon(i) \\
& -\boldsymbol{M}^{m} E(0) \ldots \ldots \ldots \ldots \ldots \ldots \ldots . \ldots \ldots \ldots
\end{aligned}
$$

\begin{tabular}{|c|c|c|c|}
\hline 節点㯴昂 & 注入箧力（筆位法） & 笛点㻎号 & 注入電力（梪位法） \\
\hline 2 & $0.5-j 0.185$ & 5 & $-0.3+j 0.18$ \\
\hline 3 & $-0.55+j 0.13$ & 6 & $-0.5+j 0.05$ \\
\hline 4 & 0.0 & & \\
\hline \multicolumn{4}{|c|}{$\begin{array}{l}\cdots, r \text { を用いて表現す机ば〔収束の条件から } \rho(\boldsymbol{M}) \\
\left.=\max _{k}\left|\lambda_{k}\right|<1\right),\end{array}$} \\
\hline \multicolumn{4}{|c|}{$\Delta(m)=\sum_{k=1}^{r} \sum_{l=1}^{m k} \boldsymbol{A}_{k l}\left\{\frac{1}{\left(1-\lambda_{k}\right)^{l}} \sum_{i=0}^{l-1} m C_{i} \lambda_{k}^{m-i}(1\right.$} \\
\hline \multicolumn{4}{|c|}{$\left.-\lambda_{k}\right)^{i} \boldsymbol{N}^{-1} I-{ }_{m} C_{l-1} \lambda_{k}{ }^{n+1-l} E(0)$} \\
\hline & $+\sum_{i=0}^{m-2} m-1-$ & & $E(i)\}+\varepsilon(m-1$ \\
\hline
\end{tabular}

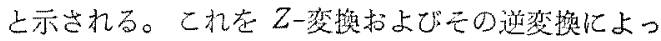
$\tau$ ，〈り返し行列 $\boldsymbol{M}$ ○買なる固有值 $\lambda_{k}, k=1,2$,
第 4 表 6 節点回路に招ける種々のスペクトル 半堡（ガウスーザイデル法）

Table 4. Various spectral radii for 6 busses system.

符 5 表 6 節点回路の注入電力

Table 5. Injection power for 6 busses system.

ただし， $m_{k}: \boldsymbol{M}$ の最小多項式における $\lambda_{k}$

の次数， $\boldsymbol{A}_{k t}$ : 文献（5）て示される行列

亡甾ける。また

$$
{ }_{m} C_{i}=m ! /\{i !(m-i) !\} \quad m<i \text { て }{ }_{m} C_{i}=0
$$

とする。

(13) 式で示される愦差は $\boldsymbol{M}$ の固有值がすへてて単根 であれば，反復計算の各ステップごしに 則的に減少していくのが扐かか，多重根をむつ場合 (特に絶対値最大の固有值の埸合) には，係数 ${ }_{m} C$ ， O 影響により規則性が失なわれ，ステップの堌加につれ て振動をもつ诚少バターンとなる。

ここで $\boldsymbol{M}$ の固有值の分布が $\left|\lambda_{1}\right|>\left|\lambda_{2}\right|>\cdots>\left|\lambda_{n-1}\right|$ の㘯合老考える。(以下で説明するが斐差評洒のアルゴ リズムは $\left|\lambda_{1}\right|>\left|\lambda_{2}\right| \geq \cdots \geq\left|\lambda_{n_{-1}}\right|$ であればよい)との とき（13）式は

$$
\begin{aligned}
\Delta(m)= & \sum_{k=1}^{n-1} A_{k}\left\{\frac{\lambda_{k}^{m}}{1-\lambda_{k}} N^{-1} I+\sum_{i=0}^{m-2} \lambda_{k}{ }^{m-1-i} \varepsilon(i)\right. \\
& \left.-\lambda_{k}{ }^{m} E(0)\right\}+\varepsilon(m-1) \ldots \ldots \ldots .(14)
\end{aligned}
$$

となり，反復計算結果の1 ステップ茎は

$$
\begin{aligned}
\delta(m) \triangleq & E(m+1)-E(m)=\Delta(m)-\Delta(m+1) \\
= & \sum_{k=1}^{n-1} \boldsymbol{A}_{k}\left(1-\lambda_{k}\right)\left\{\frac{\lambda_{k}^{m}}{1-\lambda_{k}} N^{-1} I\right. \\
& \left.+\sum_{i=0}^{m-2} \lambda_{k}^{m-1-i} \varepsilon(i)-\lambda_{k}^{m} E(0)\right\}
\end{aligned}
$$




$$
+(\boldsymbol{I}-\boldsymbol{M}) \varepsilon(m-1)-\varepsilon(m)
$$

と書ける。ここで，ある $p(m>p) に$ に扔いて $\left|\lambda_{2} / \lambda_{1}\right|^{p}$ が無視できる場合には

$$
\begin{aligned}
\sum_{k=1}^{n-1} \boldsymbol{A}_{k}\left(1-\lambda_{k}\right) & \left\{\frac{\lambda_{k}{ }^{m}}{1-\lambda_{k}} \boldsymbol{N}^{-1} I+\sum_{i=0}^{m-1-p} \lambda_{k}{ }^{m-1-i} \varepsilon(i)\right. \\
& \left.-\lambda_{k}{ }^{m} E(0)\right\}
\end{aligned}
$$

の項を $k=1$ だけで近似できるから，(14）上(15) 式を用いて

$$
\begin{aligned}
\Delta(m) & \simeq \frac{\delta(m)}{1-\lambda_{1}}-\frac{1}{1-\lambda_{1}}\left\{\sum _ { k = 2 } ^ { n - 1 } \boldsymbol { A } _ { k } \left(\lambda_{1}\right.\right. \\
& \left.-\lambda_{k}\right) \sum_{i=m-p}^{m-2} \lambda_{k}^{m-1-i} \varepsilon(i)-\left(\lambda_{1} \boldsymbol{I}-\boldsymbol{M}\right) \varepsilon(m \\
& -1)+\varepsilon(m)\} \ldots \ldots \ldots \ldots \ldots \ldots \ldots \ldots \ldots \ldots \ldots \ldots
\end{aligned}
$$

が得られる。

線形方程式では（16）式の右第二項は存在しない

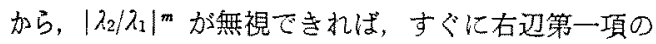
$\delta(m) /\left(1-\lambda_{1}\right)$ Kよって誤差評価ができる。(1)したがっ て，くり返し計算法の収束の早さが $\left|\lambda_{1}\right|^{m}$ 江依存する のに比べ，誤差修正法では $\left|\lambda_{2}\right|^{m^{\prime}}$ によって収束の早 さが沠まる。 $1>\left|\lambda_{1}\right| \geq\left|\lambda_{2}\right| \geq \cdots$ 加ら

$$
m / m^{\prime} \simeq \log \left|\lambda_{2}\right| / \log \left|\lambda_{1}\right| \geq 1
$$

となって，一般保差修正法は有効なととがわかる。

準線形方程式では（16）式の右辺第二項の誤差分が 存在し、乙れは評価できない。しかし反復の $p+1-ス$ テップで第一項が評価できれば，このぶんだけ誤差修 正を行なう〔すなわち反復計算をここで打ち切り，新 し小初期想定值 $E(p)+\delta(p) /\left(1-\lambda_{1}\right)$ とする こ とによって新しく出発した反復計算では $\varepsilon(i), i=0$, $1 ， 2 ， \cdots$ 著るしく減少させることができる。この上 うな過程をくり返せば収束を早められる。

さて, 初期想定值の变更を決める反復計算の打ち切 り回数 $p$ は，乘べき法の収束に要したステップ数を 用いればよい。実行中のくり返し計算法におけるくり 返し行列の最大固有值 $\lambda_{1}$ は，た之えば加速ガウスーザ イデル法の $\lambda_{1}$ は，（3）式での $\omega$ 用い次式のべク トル $V(m)$ 加ら得られるレイリ一商の収束值により 決まる。(付 1 ) 式参照〕

$$
\begin{gathered}
\dot{V}_{i^{\prime}}=\frac{1}{\dot{y}_{i i}}\left\{-\sum_{j=1}^{i-1} \dot{y}_{i j} \dot{V}_{j}(m+1)-\sum_{j=i+1}^{n-1} \dot{y}_{i j} \dot{V}_{j}(m)\right\} \\
\dot{V}_{i}(m+1)=\dot{V}_{i}(m)+\omega\left\{\dot{V}_{i}^{\prime}-\dot{V}_{i}(m)\right\} \\
\quad i=1,2, \cdots, n-1 \ldots \ldots\left(3^{\prime}\right)
\end{gathered}
$$

てれは，(3) 式で $\dot{E}_{n}, P, Q=0$ とした加速計算式 之同一である。誤差修正法を第 2 図示す。アルゴリ

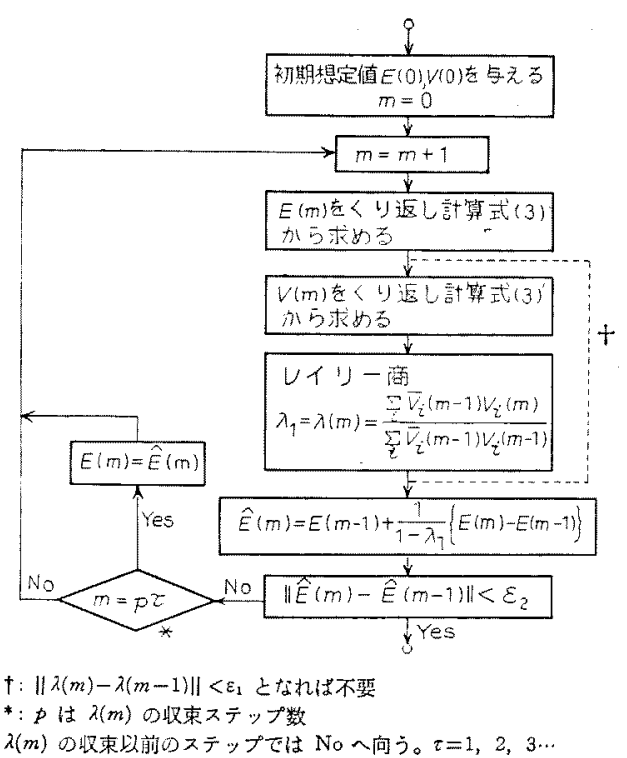

第 2 困 誤差修正法のフローチャート

Fig. 2. Algorithm of error correction method. ズムは

（i）初期想定值 $E(0), V(0)$ を与え $m=0$ とす る。

(ii) $m=m+1$ 上し，(3) 拉よび (3') 式加ら新 しい反復解 $E(m), V(m)$ を求的る。

(iii) 推定最大固有值 $\lambda_{1}$ を $\lambda_{1}(m)$

$=\sum_{i=1}^{n-1} \dot{V}_{i}(m) \bar{V}(m-1) / \sum_{i=1}^{n-1} \dot{V}_{i}(m-1) \overline{\dot{V}}_{i}(m-1)$ より求める。 $\left\|\lambda_{1}(m)-\lambda_{1}(m-1)\right\|<\varepsilon_{1}$ ならば $p$ $=m$ 亡怙き, 以後 (ii) の $V(m)$ の計算扰よび (屰)を止める。

(iv) $\hat{E}(m)=E(m-1)+\frac{1}{1-\lambda_{1}}(E(m)-E(m)$ -1)\}救的, $\|\hat{E}(m)-\hat{E}(m-1)\|<\varepsilon_{2}$ ならば, (vi) へいく。

(v) $m \neq \tau p, \tau=1,2, \cdots \cdots$ ならば（ii）へ, $m$ $=\tau p$ ならば $E(m)=\hat{E}(m)$ として(ii)へもど る。

（vi） $\hat{E}(m)$ を用いて潮流計算を行なう。

以上は絶対値最大の固有值か唯一つの場合のアルゴ リズムである。これは $\left|\lambda_{2} / \lambda_{1}\right|^{\circ}$ の項が無視できるステ ップまで反復され，(16)式の右辺第二項の誤差は評価 しないから $\left|\lambda_{1}\right|>\left|\lambda_{2}\right| \geq \cdots \geq\left|\lambda_{n-1}\right|$ の場合にも適用で きる。

なお，䜋差修正法は $1 /\left(1-\lambda_{1}\right)$ および $\{E(t)-E(t$ 
－1）の精度に大きく依存し，このため次元が増大し $\lambda_{1}$ の実部が1に近づくと，この両者のけた落ちに影響 される。したがって，回路網の分割やインピーダンス 負荷法（負荷をインピーダンスで表現する）などを適 用して，乙机らの欠点を改善する方法肪考えられる。

\section{5. くり返し行列の固有值について}

くり返し行列 $\boldsymbol{M}$ の絶対値最大の固有值 $\lambda_{1}$ とアド ミッタンス行列 $\boldsymbol{Y}$ とは密切関係する。収束条件之 して

性質 $5 \rho(\boldsymbol{M})<1$ なるための十分条件は，基準 節点を $n$ としたとき $\left|\dot{y}_{i i}\right| \geq \sum_{j \neq i}^{n-1}\left|\dot{y}_{i j}\right|, \quad i=1,2$, $\cdots, n-1$ 方満足され 1 節点以上で不等号が成立すれ ばよい。乙の性質 5 は対地キャパシタンスや基準外巻 線比変圧器, あるいは枝のリアクタンス分が容量性亡 なる位に大きな直列キャパシタが存在しない回路網で は，基準節点化隣接した節点で性質 5 の不等号が成立 し，したがって， $\rho(\boldsymbol{M})<1$ となる。一般にてれらが 存在する回路網では $\lambda_{1}$ およひび第 3 章で示した $\rho\left(S_{0}{ }^{+}\right)$ 上 $\rho\left(\boldsymbol{S}_{0}{ }^{-}\right)$学計算し，収束の判定を行なう必要がある。 次に $\lambda_{1}$ が唯一である条件を，加速なしのガウス ーザイデル法について考える。節点サセプタンス行列 の場合については論文 ${ }^{(1)}$ で述べたが，一般に節点アド ミッタンス行列の場合にも番号順の若い勘点と必ず瞵 接するように番号づけを行なえぼ(1)第 3 章の性質 1 を 満足する回路では $\boldsymbol{M}$ の実部が分解不可能な非負行列 （節点 1 を除く）となり，固有值の虚部は実部に比べて 小さいことを考えれば $\lambda_{1}$ は唯一といえる。加速定数 が增せば， $\lambda_{1}$ の実部は減り虚部は增える。

さて, $\left|\lambda_{1}\right| \simeq 1$ であったり $\rho\left(\boldsymbol{S}_{0}^{+}\right), \quad \rho\left(\boldsymbol{S}_{0}^{-}\right)<1$ が 满足されない回路条件では，回路の分割かインピーダ ンス負荷法がくり返し計算法には適当である。

インピーダンス目荷法はよく知られているように目 荷節点 $p$ をインピーダンスに表現し，

$$
1 / \dot{z}_{p 0}=\dot{y}_{p 0}=-\left(P_{p}-j Q_{p}\right) /\left|\dot{E}_{p}(0)\right|^{2} \ldots
$$

を用いて $\left[\dot{E}_{p}(0)\right.$ は推定された節点 $p$ の電生 $]$ 節点 $p$ の駆動点アドミッタンス $\dot{y}_{p p}$

$$
\dot{y}_{p p}{ }^{\prime}=\dot{y}_{p p}+\dot{y}_{p 0}
$$

に変える。負荷節点が選ばれるのは (18) および(19) 式が示すように， $\dot{y}_{\rho p}$ と $\dot{y}_{p 0}$ の実部と虚部の付号が一 致するためであり，このとき $\left|\dot{y}_{p p}{ }^{\prime}\right|>\left|\dot{y}_{p p}\right|$ となって $\rho(\boldsymbol{M})$ は小さくなる。

たとえば118 節点回路において，大きな負荷をもつ 5 個の節点をインピーダンスで表現した場合，ガウス ーザイデル法に扣ける絶対徝最大の固有值は 0.997403 一j0.000706 加ら 0.963703-j0.003674 に減少する したがって，収束は早くなる。ただし，インピーダ: スで表現された節点の推定電圧の大きさ $\left|\dot{E}_{p}(0)\right|$ 力 真の電圧の大きさ $\left|\dot{E}_{p}\right|$ 亿近くなけれは，収束しない 場合む生じるがこれについては別文にて論ずる。

\section{6. 計 算 例}

$\mathrm{AEP}$ 模擬回路である 30 節点回路についての適质 例を述へる。ここでは基準外巻線比変圧器は考えず， 基準節点を除いた全ての節点で，注入電力は指定され る。

誤差修正法とガウスーザイデル法の比較 第 3 区 で第 1 節点の実部について，両者の収束の早さを比㜞 し図示した。 $\lambda_{1}$ の収束は 1 ステップ差が $10^{-5}$ 以下に なるのに $\omega=1.0$ では 29 ステップ, $\omega=1.4$ では 17 ステップを要した。このため誤差修正法の収束曲線は このステップの整数倍付近で不安定となる。なお，真 值は注入電力の絶対值が $10^{-4}$ 以下之なったときの値 を用いた。第 4 図は加速定数を变えて計算したときの 電圧の絶対值の 1 ステップ差が $10^{-5}$ 以下となるまで に要した反復計算回数を示している。この例でわかる ように愦差修正法は加速計算法に比べ早いステップで 収束し，加速定数 $\omega$ への依存度は小さいととがわか る。ただし，最適な $\omega$ に近づくほど収束の早さの差 は小さくなってくる。てれは第5図怔示すように心 の增加によって $\lambda_{1}$ の大きさが減少し， $\lambda_{2}$ の大きさが

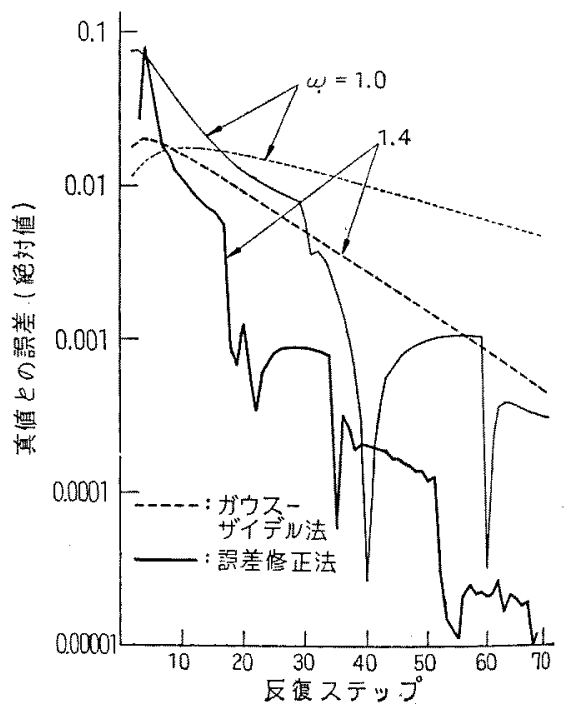

第 3 図 30 節点回路の第 1 節点（実部） の収束の比較

Fig. 3. Convergence for gauss-seidel iterative method and error correction method.(30 busses test system) 


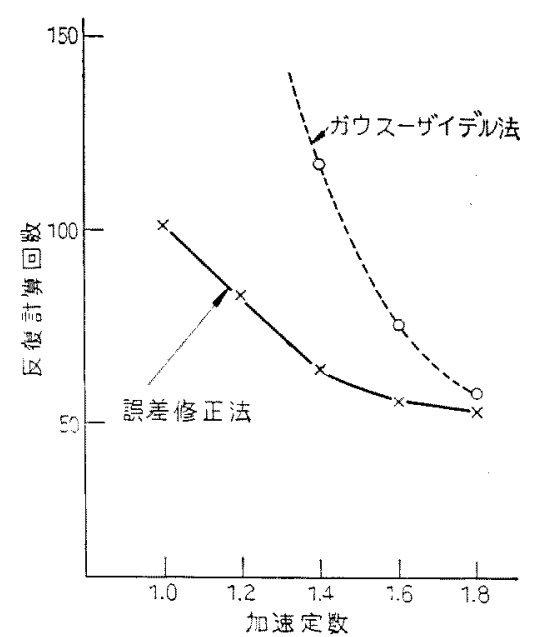

第 4 图 30 節点回路において叹束に要する反復 回数の比較 $\left(\mid 1\right.$ ステップ美 $\left.\mid<10^{-5}\right)$

Fig. 4. Effect of error correction method on the rate of convergence for Gauss-Seidel iterative method. ( 30 busses test system)

$\left|\lambda_{1}\right|$ に近づいて乗べき法が取束しないためと海えられ る。よって（17）式から雨者の収束の早さは接近した ものとなった。以上のことから誤差修正法における加

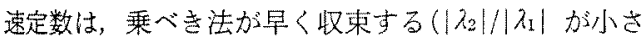
くなる）上うに選べばよいことがわかる。

収束の判定 第3図で $\omega=1.4$ のときのガウスー ザイデル法における実数部の取束の早さを示す係数 (傾豆) $\gamma_{\mathrm{real}}$ は平均して 0.9460 , 虚数部の $\gamma_{\mathrm{img}}$ 忧平 均して 0.9342 である。すなわち 1 回の及復ごとに䒠 部の誤差は $\gamma_{\mathrm{real}}$ 倍に減少していく。第3章で述べた 收束の判定に用いるスペタトル半径を重べき法により 計算した結果を第 6 表に示す。この表から

$$
\rho(\boldsymbol{M}) \leq \gamma_{\text {real }}<\rho\left(\boldsymbol{S}_{k}^{-}\right)
$$

関係が得られる。また近似計算 $\rho\left(\boldsymbol{S}_{0}^{-}\right)$むよび $\rho$

$\left(\boldsymbol{S}_{0}{ }^{+}\right)$は收束判定に便利な指標であることがかかる。

第 6 表 30 節点回路における種々なスペクトル半径 Table 6. Various spectral radii for 30 busses test system.

\begin{tabular}{|c|c|}
\hline & 加速定数 $\quad \omega=1.4$ \\
\hline$\rho(M)$ & $|0.942023+j 0.011206|$ \\
\hline$\rho\left(S_{k^{-}}\right)$ & $|0.957716+j 0.018065|$ \\
\hline$\rho\left(S_{k}+\right)$ & $|0.926218+j 0.004468|$ \\
\hline$\rho\left(S_{0}^{-}\right)$ & $10.951087+j 0.0250221$ \\
\hline$p\left(S_{0}{ }^{+}\right)$ & $|0.932784-j 0.002603|$ \\
\hline$\frac{\left.\| E_{1}-E_{1}(70)\right\} \text { real } \mid}{\mid\left[E_{1}-E_{1}(69) \mid \text { reat } \mid\right.}$ & 0.9464 \\
\hline 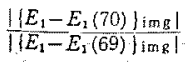 & 0.9345 \\
\hline
\end{tabular}

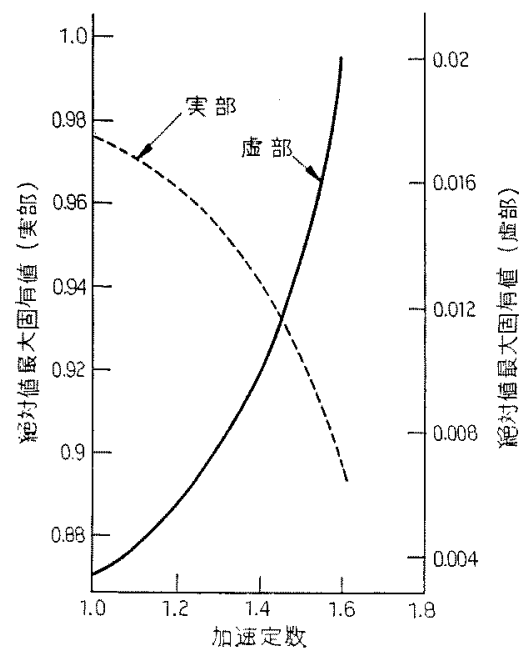

第 5 図 30 節点回路の絶対值最大固有値 (ガウスーザイデル法)

Fig. 5. Relation between maximal eigenvalue of $\mathrm{M}$ and acceleration factor for 30 busses test system.

な打（8)，(9) 式加示すように $\rho\left(\boldsymbol{S}_{0}^{-}\right)$は㻨圧の実 部の収束に関係吉る。

\section{7.むすび}

本論文でくり返し棓算法を線形方程式ではない雪力 潮流計算に適用した場合の収束の判定かよび真值との 琶差の関係加導加れ，この誤考解析加らくり返し計算 法の収束を早好る䛊差修正法を潐線形問題八適用する アルゴリズムが得られた。

誤差修正法はくり返し計算法の利点在保持でき，加 速計算法より古収束は早いなどの利点を有する。また， 本文で得られた収束の判定法は徒来明自でなかった潮 流計算の収束を判定するのに役だつと考えられる。こ れによってくり返し計算法沶よび䛊差修正法が適用可 能ないくつかの回路条件が得られたが，また，適用不 可能な揚合毛明らかになった。この中で回路網の次元 の增大はくり遮し計算法の収束を可能化する基染節点 に隣接した枝のインピーダンス効果を小さくすること や，誤差修正法の精度を悪くすることになり，数百次 元の回路では解析できなくなる上考えられる。

現在，Tinney 氏らの最燠順序つけ消去法在用いて 大次元回路をニュートンーラフソン法で船く方法 ${ }^{(4)}$ と. 回路紨を分制して，佂来の方式在㠃用する若えがある

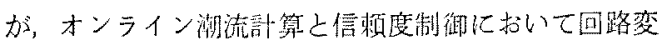
更や入力処理を含む計算時間を考愿すれば後者が有力 である。しかし，分割の方式や潮流計算の収束の議諭 
はいまだ明白でなく，今後に残された問題である。

なお，本諭文では基整節点を除いてす心゙て $P-Q$ 指 定ししたが，一般に $P-V$ 指定の節点が存在する。こ れは収束の議論を複雑にするが、インピーダンス負荷 法の収束とと屯に今後論ずる必要があるう。

また，誤差修正法に扣ける加速定数の選报の問題も 今後議論していきたい。

(昭和46年11月27日受付，同47年3月29日再受付)

\section{文献}

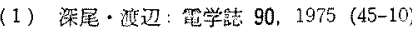

(2) G. W. Stagg: Conputer Methods in Power System Ana* lysis (1968) McGraw.Hill

(3) J.H. Wilkinson: The Algebraic Eigenvalue Problem, (1965) Clarendon Press. Oxford,

(4) W.F. Tinney \& C.E Hart: IEEE Trans. Power Apparatus Syst., PAS-86, No. 11 p. 1449 (1967)

(5) T. Fukao \& S. Watanabe: "Error and Limitation of Network Size in Iterative Method for Large Scale Power System Network," presented at the IEEE Winter Power Meeting, (1971) New York, N.Y.,

(6) R.S. Varga: Matrix Iterative Analysis, (1962) Prentice-Hall

(7) E. Isaacson \& H.B. Keller: Analysis of Numerical Methods (1966) John Wiley \& Sons

\section{付 録}

（I）絶対值最大の固有值の計算乘べき法は行 列 $\boldsymbol{M}$ の絶対值最大の固有值 $\lambda_{1}$ に刘応する固有べク トル $V$ を反復計算により求める方法である。すなわ ち雾でない初期ベタトルV $V(0)$ 加ら出発して

$$
V(m)=\boldsymbol{M} V(m-1)
$$

を反復計算していけばよい。（付1)式は（4）式に㧤 いて， $I(m)=0$ としたことに他ならないから，基準 節点の行と列索除いた節点アドミッタンス行列を用い

$$
\boldsymbol{Y} V=0
$$

をヤコビ法，ガウスーザイデル法または加速計算法で 反復計算すれば，收柬したベクトルVがそれぞれの 計算法に対応したくり返し行列の $\lambda_{1}$ の固有ベクトル になる。このとき $\lambda_{1}$ はレイリ一阎（ベクトルの内璝 の比）により精度よく計算され

$$
\lambda_{1}=\frac{\sum_{i} V_{i}(m+1) \cdot \overline{\boldsymbol{V}}_{i}(m)}{\sum_{i} V_{i}(m) \cdot \overline{\boldsymbol{V}}_{i}(m)}
$$

となる。このととは（13）式の尊出亡同様に（付 1 ) 式の $z$-変捂およびその逆変換から〔係数は（13）式 参照了

$$
V(m)=\sum_{k=1}^{r} \sum_{l=1}^{m k} \boldsymbol{A}_{k l m} C_{l-1} \lambda_{K}^{m+1-l} \boldsymbol{V}(0)
$$

が得られ，したがって $\lambda_{1}$ が単根で $\left|\lambda_{2} / \lambda_{1}\right|^{m}$ が無視で きる $m$ ステップ以後では，(付 3 ）式から $\lambda_{1}$ が求め られる。また $\lambda_{1}$ の収束過程から， $\lambda_{2}$ 以下の固有值が 無視できる計算回数が定められる。なお $V(m)$ は， $\lambda_{1}<1$ であることから雾べクトルに収束するので，た 上えば(付1) 式で

$$
\begin{aligned}
& V^{\prime}(m)=\boldsymbol{M} V(m-1) \\
& V(m)=V^{\prime}(m) / \sum_{i} V_{i}^{\prime}(m) \cdot \bar{V}_{i}^{\prime}(m)
\end{aligned}
$$

と正規化して反復計算する。このとき（付 3）式は，

$$
\begin{aligned}
& \lambda_{1}=\sum_{i} \bar{V}_{i}(m) V_{i}^{\prime}(m+1) \ldots \ldots \ldots \ldots \ldots \\
& \text { ここで } \bar{V}_{i}(m): V_{i}(m) \text { の共役複素数 }
\end{aligned}
$$
となる。(7)

(II) $\rho\left(\boldsymbol{S}_{k^{-}}\right)$およひ $\rho\left(\boldsymbol{S}_{k^{+}}\right)$の計算 加速定数 $\omega$ のガウスーザイデル法の乗べき計算は，（付 1 ）式を各 要素に慧きなおせば（基準節点は $n$ 番目）

$$
\left.\begin{array}{c}
\dot{V}_{i}{ }^{\prime}=-\frac{1}{\dot{y}_{i i}}\left\{\sum_{j=1}^{i-1} \dot{y}_{i j} \dot{V}_{j}(m)\right. \\
\left.+\sum_{j=i+1}^{n-1} \dot{y}_{i j} \dot{V}_{j}(m-1)\right\} \\
\left.\dot{V}_{i}(m)=\dot{V}_{i}(m-1)+\omega \dot{V}_{i}-\dot{V}_{i}(m-1)\right\} \\
i=1,2, \cdots, n-1
\end{array}\right\}
$$

と示される。このとき（付 3) 式によって $\rho(\boldsymbol{M})$ に 絶対值方等しい $\lambda_{1}$ が求められる。しかるに $\rho\left(\boldsymbol{S}_{k}{ }^{-}\right)$ 扰上び $\rho\left(\boldsymbol{S}_{k}^{+}\right)$は (9) 扔上び (10) 式加示すように （付6）式の $V^{\prime}$ の右辺へそれぞれ，

$$
\begin{aligned}
& -\frac{1}{\dot{y}_{i i}} \frac{P_{i}-j Q_{i}}{\bar{E}_{i} \dot{E}_{i}(k)} \dot{V}_{i}(m-1) \text { およひ } \\
& \frac{1}{\dot{y}_{i i}} \frac{P_{i}-j Q_{i}}{\vec{E}_{i} \dot{E}_{i}(k)} \dot{V}_{i}(m-1) \quad \ldots \ldots \ldots . .
\end{aligned}
$$

を加えて反復計算し（付 3 ) 式を計算するととによ り求めら妃る。

近似尌算では僻々の $k$ (ステッッフ数)に和ける $\left(\boldsymbol{S}_{k}^{-}\right)$と $\rho\left(\boldsymbol{S}_{k^{+}}\right)$在求めず，（付 7$)$ 式の代わりに

$$
\mp \frac{1}{\dot{y}_{i i}} \frac{P_{i}-j Q_{i}}{\left\{\dot{E}_{i}(m-1)\right\}^{2}} \dot{V}_{i}(m-1)
$$

を用いる。良 $(m-1)$ は $m=1$ から同時にはじまるく り返し計算法により得られる。また，この $\dot{E}(m-1)$ を用いずに近似した $\rho\left(\boldsymbol{S}_{0}^{-}\right)$と $\rho\left(\boldsymbol{S}_{0}^{+}\right)$は（付7） 式の代わりに

$$
\mp \frac{1}{\dot{y}_{i i}}\left(P_{i}-j Q_{i}\right) \dot{V}_{i}(m-1)
$$

を(付6) 式の $\dot{V}_{i}^{\prime}$ の右辺へ加え，反復計算される。 